\title{
Clinical Evaluation of the Minitek Differential System for Identification of Enterobacteriaceae
}

\author{
PATRICIA J. FINKLEA,* MARSHA S. COLE, AND THOMAS M. SODEMAN \\ Department of Pathology, Microbiology Section, University Hospital, Ann Arbor, Michigan 48109
}

Received for publication 8 July 1976

\begin{abstract}
Forty-one stock organisms and 581 fresh clinical isolates were used in comparing the Minitek system to conventional tubed media to determine if this system is feasible and accurate for a high-volume clinical microbiology laboratory. In addition to comparison with tubed media, the following parameters were tested: (i) reproducibility of disks, (ii) the effect of variation in inoculum size, (iii) the effect of the age of culture, and (iv) the effect of predispensing disks. A total of 5,947 disks were compared with tube reactions; $95.9 \%$ agreed on the initial reading. After repeating questionable tube and disk reactions, this agreement rose to $98.2 \%$. Using the disk reactions and the identification schema currently in use with tubed media, $94.9 \%$ of the Minitek final identifications agreed with those of tubed media; $1.5 \%$ gave differing identifications and $3.6 \%$ were inconclusive. This system is accurate, inexpensive, flexible, and convenient.
\end{abstract}

Members of Enterobacteriaceae are among the most common organisms isolated in the clinical laboratory. Several miniaturized systems have been marketed to facilitate identification of these organisms. Minitek (Bioquest, Div. of Becton, Dickinson and Co., Cockeysville, Md.), based upon substrate impregnated disks, is such a system. It was evaluated for its accuracy of both organism identification and individual biochemical reactions.

(This paper was presented at the 1974 national meeting of the American Society of Clinical Pathologists, Washington, D.C.)

\section{MATERIALS AND METHODS}

The Minitek system consists of a small plastic plate with wells, cartridges of substrate disks which are dispensed into the wells, an inoculum broth, and a pipette gun set to deliver $0.05 \mathrm{ml}$ of the inoculated broth onto each disk. Some inoculated disks are overlaid with sterile mineral oil, and the plates are incubated in a humidor. Both sterile and nonsterile tips were used with the pipette gun. No evidence of contamination was found with the nonsterile tips, and they were easier and less expensive to use than the sterile tips. The manufacturer's directions were followed with these modifications. (i) The inoculum was homogenized with the pipette gun rather than being vortexed. (ii) Oil was dispensed with an autoclavable Oxford dispenser model $\mathrm{S}$, set to deliver $0.15 \mathrm{ml}$ of oil. (iii) A triple sugar iron slant and a motility tube were inoculated in addition to Minitek disks. (iv) Indole production was tested by (a) using the $\mathrm{H}_{2} \mathrm{~S}$ disk - both $\mathrm{H}_{2} \mathrm{~S}$ and indole reactions are read from the $\mathrm{H}_{2} \mathrm{~S}$ disk, and (b) inoculating the broth into an empty well for incubation (open well).
Before comparing the Minitek with the conventional tube system, preliminary work was performed to evaluate sensitivity of Minitek to a variety of parameters. The conventional media used in this comparison included: (i) commercially prepared media from BBL (Bioquest, Division of Becton, Dickinson \& Co., Cockeysville, Md.) consisting of triple sugar iron, $2 \%$ tryptone, citrate, urea broth; phenylalanine, lysine, arginine, ornithine, adonitol, arabinose, raffinose, rhamnose, sorbitol, inositol, xylose, and maltose; and (ii) homemade media prepared from Difco dehydrated media consisting of MR-VP, motility, and malonate. Reproducibility' of disk reactions was checked by testing 47 substrate lots (a total of 3,859 disks) with known organisms. Up to 100 disks of each lot available were inoculated, half with an organism giving a positive reaction and half with an organism giving a negative reaction.

Potential variation of results due to differing inoculum size was tested using one colony versus six to eight colonies per diluent broth for eight organisms in 182 tests. Effect of culture age was tested using 1-, 2-, 3-, 4-, and 5-day-old cultures of four organisms in 156 tests. Disks were predispensed to the plastic plates, refrigerated at $8^{\circ} \mathrm{C}$ from 1 to 7 days before use, and evaluated for reproducibility by a total of 462 tests with three organisms.

Comparisons of biochemical reactions and organism identifications were made between the Minitek and conventional tube systems. All clinical isolates were inoculated into the Minitek broth from a 24-h MacConkey plate and taken to one of three biochemical patterns depending on the colony morphology (Table 1).

Conventional tubed media were run in parallel according to routine procedures. Both tubed media and Minitek were incubated for 18 to $24 \mathrm{~h}$ at $35^{\circ} \mathrm{C}$. Reagents were added, results were read, and orga- 
nism identification was made according to the charts of Edwards and Ewing (1). If the results of the two systems did not agree, the test was repeated in both systems.

\section{RESULTS}

Parameter testing. Thirteen of the 17 different disks (comprising 38 lots and 2,674 disks) were evaluated for reproducibility and gave $100 \%$ appropriately negative or positive reactions. The remaining four substrates, arginine (two lots tested), citrate (two lots tested), ornithine (four lots tested), and xylose (one lot tested), gave less than $100 \%$ appropriate results (Table 2). The other three parameters tested, i.e., the effects of culture age, inoculum size, and predispensed disks, caused no detectable variations from the expected reaction patterns.

Comparison of tube versus disk. A total of 5,947 disks were compared with the tube reactions. When initial disk and tube reactions dis-

TABLE 1. Minitek biochemical patterns used

\begin{tabular}{lll}
\hline \multicolumn{1}{c}{ Pattern $1^{a}$} & Pattern $2^{b}$ & Pattern ${ }^{c}$ \\
\hline $\mathrm{H}_{2} \mathrm{~S}$ & $\mathrm{H}_{2} \mathrm{~S}$ & $\mathrm{H}_{2} \mathrm{~S}$ \\
Disk indole & Disk indole & Disk indole \\
Open indole & Open indole & VP \\
VP $^{d}$ & Citrate & Citrate \\
Citrate & Adonitol & Malonate \\
Malonate & Urea & Lysine \\
Lysine & Phenylalanine & Arginine \\
Adonitol & Ornithine & Ornithine \\
Urea & Inositol & Adonitol \\
Phenylalanine & Xylose & Arabinose \\
& Maltose & Raffinose \\
& & Rhamnose \\
& & Sorbitol \\
\hline
\end{tabular}

${ }^{a}$ Pattern 1, Flat lactose positive; flat lactose negative, non-Proteus.

b Pattern 2, Flat lactose negative, i.e., Proteus.

c Pattern 3, Mucoid, lactose positive, lactose variable.

d VP, Voges-Proskauer.

Table 2. Disk lot variability

\begin{tabular}{lrrrr}
\hline & Lot no. & $\begin{array}{c}\text { No. of } \\
\text { disks } \\
\text { tested } \\
\text { per lot }\end{array}$ & \multicolumn{2}{c}{$\begin{array}{c}\text { \% Agreement } \\
\text { with appropri- } \\
\text { ate reaction }\end{array}$} \\
\cline { 4 - 6 } & & $\begin{array}{c}\text { Posi- } \\
\text { tive }\end{array}$ & $\begin{array}{c}\text { Nega- } \\
\text { tive }\end{array}$ \\
\hline Arginine & 311062 & 100 & 92 & 100 \\
& 403078 & 75 & 98 & 100 \\
Citrate & 402014 & 150 & 84 & 98 \\
& 404108 & 150 & 94 & 100 \\
Ornithine & 402013 & 100 & 100 & 100 \\
& 404019 & 100 & 100 & 100 \\
& 407029 & 28 & 100 & 100 \\
& 311072 & 32 & 50 & 100 \\
Xylose & 311075 & 150 & 100 & 68 \\
\hline
\end{tabular}

agreed, both were repeated and a confirmed tube reaction was considered correct. Of the total disks and tubes compared, $95.9 \%$ agreed on initial reading. After repeating questionable results, this figure rose to $98.2 \%$.

Table 3 indicates the initial and final correlation of each type of disk with the tubed media. Fifteen of the 20 reactions tested gave an initial agreement of $95 \%$ or higher. The five exceptions were $\mathrm{H}_{2} \mathrm{~S}$ lot 402019 , disk indole, citrate, ornithine, and xylose. Table 4 demonstrates that most initially disagreeing disks were negative when the corresponding tube was positive.

The $\mathrm{H}_{2} \mathrm{~S}$ lot 402019 was the first production lot released by the manufacturer and appeared too sensitive, giving false-positive reactions. The false-positive $\mathrm{H}_{2} \mathrm{~S}$ reaction was corrected in subsequent lots of $\mathrm{H}_{2} \mathrm{~S}$ disks, which gave a 98.0\% initial correlation with the tubed media and a $99.4 \%$ final agreement. For this reason

TABLE 3. Disk agreement

\begin{tabular}{|c|c|c|c|}
\hline \multirow{2}{*}{ Test disk } & \multirow{2}{*}{$\begin{array}{l}\text { No. } \\
\text { tested }\end{array}$} & \multicolumn{2}{|c|}{$\%$ Agreement } \\
\hline & & Final & Initial \\
\hline $\mathrm{H}_{2} \mathrm{~S}$ (lot 402019) & 301 & No repeat & 88.7 \\
\hline $\mathrm{H}_{2} \mathrm{~S}$ (lot 405017) & 352 & 99.4 & 98.0 \\
\hline Indole (open well) & 433 & 96.8 & 95.8 \\
\hline Indole (disk) & 632 & 96.7 & 89.9 \\
\hline Voges-Proskauer & 445 & 99.8 & 99.1 \\
\hline Citrate & 573 & 98.8 & 94.6 \\
\hline Malonate & 281 & 99.6 & 98.9 \\
\hline Lysine & 390 & 99.2 & 98.5 \\
\hline Arginine & 156 & 99.4 & 98.1 \\
\hline Ornithine & 435 & 92.0 & 91.5 \\
\hline Adonitol & 402 & 99.5 & 98.8 \\
\hline Arabinose & 171 & 100.0 & 99.4 \\
\hline Raffinose & 194 & 99.5 & 98.4 \\
\hline Rhamnose & 194 & 100.0 & 98.4 \\
\hline Sorbitol & 194 & 99.5 & 97.4 \\
\hline Urea & 319 & 98.7 & 98.4 \\
\hline Phenylalanine & 246 & & 100.0 \\
\hline Inositol & 129 & & 100.0 \\
\hline Xylose & 74 & 95.9 & 85.1 \\
\hline Maltose & 26 & 100.0 & 96.2 \\
\hline Total & 5,947 & 98.2 & 95.9 \\
\hline \multicolumn{4}{|c|}{ TABLE 4. Problem disks } \\
\hline \multirow[b]{2}{*}{ Test disk } & \multirow[b]{2}{*}{$\begin{array}{l}\text { No. disa- } \\
\text { gree/total }\end{array}$} & \multicolumn{2}{|c|}{$\begin{array}{l}\text { Disagreeing results } \\
(\%)\end{array}$} \\
\hline & & $\begin{array}{c}\text { + with } \\
\text { Minitek, } \\
\text { - with } \\
\text { tube }\end{array}$ & $\begin{array}{c}\text { - with } \\
\text { Minitek, } \\
\text { + with } \\
\text { tube }\end{array}$ \\
\hline Indole (open well) & $18 / 433$ & 5.6 & 94.4 \\
\hline Indole (disk) & $64 / 632$ & 3.1 & 96.9 \\
\hline Citrate & $31 / 573$ & 12.9 & 87.1 \\
\hline Ornithine & $39 / 435$ & 5.1 & 94.9 \\
\hline Xylose & $11 / 74$ & 90.9 & 9.1 \\
\hline
\end{tabular}


the results of the $\mathrm{H}_{2} \mathrm{~S}$ testing are divided into lot 402019 and lot 405017.

Since indole production was tested with the $\mathrm{H}_{2} \mathrm{~S}$ disk and open well, these results are divided into two sections. The open-well indole (inoculum plus reagent) gave consistently good reactions throughout the study with only a $1 \%$ improvement upon repeating questionable reactions. As Table 4 demonstrates, $94.4 \%$ of the 18 disagreeing results were due to negative Minitek indoles as opposed to positive tube reactions. However, five of these indole tube reactions were positive only after $48 \mathrm{~h}$ of incubation. Fourteen of the 17 strains giving negative Minitek indole were species of Proteus. The disk indole test had an initial agreement with tubed media of only $89.9 \%$. However, since the disk indole reaction is read from the $\mathrm{H}_{2} \mathrm{~S}$ disk, it is possible that lot $402019 \mathrm{H}_{2} \mathrm{~S}$ disks also gave misleading indole reactions. When the tests were repeated with a new lot a final $96.7 \%$ disk agreement compared well with the $96.8 \%$ final open well. As with the open-well indole (Table 4), $96.9 \%$ of the 64 disagreeing Minitek disk indoles were negative when the tube indole was positive. Forty of the 59 affected strains were Proteus. The pattern of negative Minitek indoles was inconsistent: some strains had a negative disk and a positive open-well indole; some strains had positive disk and a negative openwell indole; some had negative open-well and disk indole with a weakly positive tube indole. Two strains of Proteus that were indole positive by Minitek and negative by tube had other biochemical reactions that suggested that a positive indole was the expected result.

Citrate was another problem disk with some organisms. Minitek disks most often gave initially negative results when tube results were positive (Table 4). The $87.1 \%$ includes 11 Citrobacter, 5 Proteus, and 11 Enterobacter. After the citrate was repeated, seven organisms remained citrate negative. As with the $\mathrm{H}_{2} \mathrm{~S}$, the earlier lots of citrate had more disagreeing results than the later lots when the problem strains were retested.

Ornithine follows the pattern of indole and citrate (Table 4) in that $94 \%$ of the 39 disagreeing reactions are negative with Minitek and positive in $24 \mathrm{~h}$ with tubed media. Thirty-four out of $37(94.9 \%)$ of these false-negative readings were Proteus, and 31 of these were Proteus morganii. Even after incubating the ornithine disk for $48 \mathrm{~h}$, and retesting these organisms with different lots of ornithine, 29 of 35 P. morganii strains continued to give persistently negative Minitek results.

The ornithine disks have been modified since this study was completed (D. Mayfield, Bioquest, personal communication), and the 31 strains of $P$. morganii do give a positive reaction in $24 \mathrm{~h}$ using the modified disk.

The 11 disagreeing disk of xylose, in contrast to the other disks discussed, were $90.9 \%$ positive when the tubes were negative. This is a result of heat sensitivity of this sugar with a loss of activity during production. The necessary changes are being made to correct this (Mayfield, personal communication).

Comparison of final identifications. Table 5 shows a $92.1 \%$ initial agreement and a $94.9 \%$ final agreement, with $1.3 \%$ wrong identifications and $3.8 \%$ inconclusive results needing further testing. Table 6 provides more specific information about the strains studied. Of the 19 species included in this study, 11 had identifications agreeing 95 to $100 \%$ with the tubed-media identifications. For an identification to agree, we required that all Minitek disks crucial to identification agree with the tube. A dichotomous schema was not used and, depending on a particular laboratory's requirements for identification, the percentage of final correlation using our disk results could be higher or lower.

Table 6 shows that Citrobacter freundii had a 83.7\% initial and $93.0 \%$ final identification agreement. The seven initial and two final inconclusive identifications of $C$. freundii were based upon citrate-negative disk reactions and positive tube reactions. It should also be noted that the Citrobacter species sometimes gives a strongly positive urea on the Minitek when a urea broth is negative. Since urease production is expected in some citrobacters such a reaction suggests that the Minitek urea disks are more sensitive than urea broth.

The $P$. morganii presented the single largest group of problem identifications. Because 29 of 35 strains were ornithine disk negative, the $\mathrm{H}_{2} \mathrm{~S}$, indole, citrate, adonitol, and inositol reactions were used to identify this species. Even using these five reactions, only $77.1 \%$ were finally identified as $P$. morganii when compared with the results from tubed media. Six $P$. morganii were also indole negative on the Minitek. Since others $(2,3)$ have not reported a similar problem, it is possible that this reaction pattern is due to a strain variation.

Proteus vulgaris and Providencia both fall

TABLE 5. Organism identification summary

\begin{tabular}{cccc}
\hline $\begin{array}{c}\text { Minitek read- } \\
\text { ings }\end{array}$ & $\begin{array}{c}\text { Agreement } \\
(\%)\end{array}$ & $\begin{array}{c}\text { Wrong identi- } \\
\text { fication (\%) }\end{array}$ & $\begin{array}{c}\text { Inconclusive } \\
(\%)\end{array}$ \\
\hline Initial & 92.1 & 0.6 & 7.3 \\
Final & 94.9 & 1.3 & 3.8 \\
\hline
\end{tabular}


below the 95\% final agreement because of indole disk-negative strains: 1 out of 19 strains of $P$. vulgaris and 2 out of 7 Providencia.

There were a variety of reasons that the six species of Klebsiella, Serratia, and Enterobacter fell below $95 \%$ final agreement with the tube identification (Table 6). There were no trends within a species and no single disk was a predominant cause of inconclusive or wrong identifications. Table 7 shows the seven wrong identifications out of the 622 strains studied.

\section{DISCUSSION}

The parameter testing with the Minitek dem-

TABLE 6. Identification comparison ${ }^{a}$

\begin{tabular}{|c|c|c|c|c|c|}
\hline Organism & $\begin{array}{l}\text { No. of } \\
\text { strains }\end{array}$ & $\begin{array}{c}\text { Minitek read- } \\
\text { ings }\end{array}$ & Agreement (\%) & $\begin{array}{l}\text { Wrong iden- } \\
\text { tification }(\%)\end{array}$ & Inconclusive (\%) \\
\hline Escherichia coli & 116 & $\begin{array}{l}\text { Initial } \\
\text { Final }\end{array}$ & $\begin{array}{l}99.1 \\
99.1\end{array}$ & & $\begin{array}{l}0.9 \\
0.9\end{array}$ \\
\hline Citrobacter freundii & 43 & $\begin{array}{l}\text { Initial } \\
\text { Final }\end{array}$ & $\begin{array}{l}83.7 \\
93.0\end{array}$ & 2.4 & $\begin{array}{r}16.3 \\
4.6\end{array}$ \\
\hline Proteus mirabilis & 121 & $\begin{array}{l}\text { Initial } \\
\text { Final }\end{array}$ & $\begin{array}{l}96.7 \\
97.5\end{array}$ & 0.9 & $\begin{array}{l}3.3 \\
1.6\end{array}$ \\
\hline P. morganii & 35 & $\begin{array}{l}\text { Initial } \\
\text { Final }\end{array}$ & $\begin{array}{l}71.4 \\
77.1\end{array}$ & 2.9 & $\begin{array}{l}28.6 \\
20.0\end{array}$ \\
\hline P. vulgaris & 19 & $\begin{array}{l}\text { Initial } \\
\text { Final }\end{array}$ & $\begin{array}{l}89.5 \\
91.7\end{array}$ & & $\begin{array}{r}10.5 \\
8.3\end{array}$ \\
\hline Providencia & 7 & $\begin{array}{l}\text { Initial } \\
\text { Final }\end{array}$ & $\begin{array}{l}71.5 \\
71.5\end{array}$ & & $\begin{array}{l}28.5 \\
28.5\end{array}$ \\
\hline Klebsiella pneumoniae & 72 & $\begin{array}{l}\text { Initial } \\
\text { Final }\end{array}$ & $\begin{array}{l}94.4 \\
94.4\end{array}$ & $\begin{array}{l}1.4 \\
2.8\end{array}$ & $\begin{array}{l}4.2 \\
2.8\end{array}$ \\
\hline Serratia marcescens & 51 & $\begin{array}{l}\text { Initial } \\
\text { Final }\end{array}$ & $\begin{array}{l}92.2 \\
98.0\end{array}$ & & $\begin{array}{l}7.8 \\
2.0\end{array}$ \\
\hline Enterobacter aerogenes & 37 & $\begin{array}{l}\text { Initial } \\
\text { Final }\end{array}$ & $\begin{array}{l}91.9 \\
94.6\end{array}$ & $\begin{array}{l}5.4 \\
5.4\end{array}$ & 2.7 \\
\hline E. cloacae & 53 & $\begin{array}{l}\text { Initial } \\
\text { Final }\end{array}$ & $\begin{array}{l}83.0 \\
90.6\end{array}$ & 1.9 & $\begin{array}{r}17.0 \\
7.5\end{array}$ \\
\hline E. agglomerans & 8 & $\begin{array}{l}\text { Initial } \\
\text { Final }\end{array}$ & $\begin{array}{l}62.5 \\
87.5\end{array}$ & & $\begin{array}{l}37.5 \\
12.5\end{array}$ \\
\hline E. hafniae & 5 & $\begin{array}{l}\text { Initial } \\
\text { Final }\end{array}$ & $\begin{array}{r}60.0 \\
100.0\end{array}$ & & 40.0 \\
\hline
\end{tabular}

a This table does not include the following organisms because the initial Minitek and tube identifications agreed 100\%: Edwardsiella (3 strains), Shigella (5), Salmonella (7), Arizona (3), Citrobacter diversus (16), Proteus rettgeri (16), and Serratia liquefaciens (2).

TABLE 7. Identification errors in the Minitek system

\begin{tabular}{lll}
\hline \multicolumn{1}{c}{ Organism } & Minitek identification & \multicolumn{1}{c}{ Reasons $^{a}$} \\
\hline C. freundii & E. coli & Disk indole positive, citrate negative \\
$P$. mirabilis & P. morganii & Open indole positive, $\mathrm{H}_{2} \mathrm{~S}$ negative \\
$P$. morganii & P. mirabilis & Indole negative \\
K. pneumoniae & E. aerogenes & Ornithine positive \\
K. pneumoniae & E. agglomerans & Lysine and citrate negative \\
E. aerogenes & E. hafniae & Voges-Proskauer, citrate, sorbitol, and raffinose negative \\
E. cloacae & $E$. agglomerans & Arginine and ornithine negative \\
\hline
\end{tabular}

\footnotetext{
a Inaccurate Minitek reaction.
} 
onstrated that reasonable variation in inoculum size and age of culture when inoculated into broth had no effect on the results. Disks may be predispensed to the plastic plates on a weekly basis, refrigerated, and used as needed. Some lot to lot variation in the disks, especially with earlier lots, dictates that quality control must be done on all new lots of disks. No deterioration of any of the lots over the 6-month period was noticed. The disks have a manufacturer's 2-year outdate.

For work with this system, we recommend using one, rather than three, disk patterns to eliminate the possibility of inoculating an organism to the wrong pattern. Our suggested pattern includes a tube motility and the following disks: $\mathrm{H}_{2} \mathrm{~S}$-indole, Voges-Proskauer, citrate, $o$ nitrophenyl- $\beta$-D-galactopyranoside, phenylalanine, urea, lysine, ornithine, adonitol, inositol, arabinose and sorbitol. Of 116 additional organisms inoculated using this pattern, only two required additional work on the second day to complete the identifications.

Minitek is a convenient system to use. The plates were inoculated in a fraction of the time needed to inoculate equivalent tubed media, and the inoculum was more uniform to each substrate. The relatively large number of tests per plate (up to 12) helps eliminate possible misidentifications and shortens the number of days needed to identify an organism. Because of the flexibility of this system, it has been expanded to the identification of anaerobes (4) and pathogenic Neisseria (D. C. Mayfield, G. L. Wans, and C. A. Fien, Abstr. Annu. Meet. Am. Soc. Microbiol. 1976, C18, p. 29). It also has the potential for expansion to the identification of nonfermenters and yeasts. The fact that the system is accurate, and in addition compact and reliable, presents a distinct advantage over the conventional tube system.

\section{LITERATURE CITED}

1. Edwards, P. R., and W. H. Ewing. 1972. Identification of Enterobacteriaceae. Burgess Publishing Co., Minneapolis, Minn.

2. Hansen, S. L., D. R. Hardesty, and B. M. Myers. 1974 Evaluation of the BBL Minitek system for the identification of Enterobacteriaceae. Appl. Microbiol. 28:798-801.

3. Kiehn, T. E., K. Brennan, and P. D. Ellner. 1974 Evaluation of the Minitek system for identification of Enterobacteriaceae. Appl. Microbiol. 28:668-671.

4. Stargel, M. D., F. S. Thompson, S. E. Phillips, G. L. Lombard, and V. R. Dowell, Jr. 1976. Modification of the Minitek miniaturized differentiation system for characterization of anaerobic bacteria. J. Clin. Microbiol. 3:291-301. 